\title{
Methiin 食シロネズミの血清コレステロール值の変動
}

\section{S-Methyl-L-Cysteine Sulfoxide (Methiin) の抗コレステロール作用（第 1 報）}

\author{
松 本 和*, 系 川嘉 則**, 藤 原 元 典** \\ *高知学園短期大学 \\ **京都大学医学部葦生学教室
}

\begin{abstract}
Effect of S-Methylcysteine Sulfoxide on Serum Cholesterol Level of Rat Anti-Hypercholesterolemic Eftect of S-Methylcysteine Sulfoxide (Part 1)
\end{abstract}

\author{
Kazu Matsumoto, ${ }^{*}$ Yoshinori Itokawa, ${ }^{* *}$ Motonori Fujiwara** \\ * Kochi Gakuen Junior College, Asahitenjin, Kochi \\ **Department of Hygiene, Faculty of Medicine, Kyoto University, Sakyo-ku, Kyoto
}

J. Japan Soc. Food and Nutr. 24(4) 249 252 (1971)

In a continuing study on nutritional values of S-methyl-L.cysteine sulfoxide (methiin), a sulfur containing amino acid extracted from cabbage, authors investigated anticholesterolemic effect of this substance for experimental hypercholesterolemia rat.

Addition of S-methyl-L-cysteine sulfoxide to a cholesterol containing diet markedly prevented the increase of serum cholesterol level of rat, in contrast the control rats produced a hypercholesterolemia by cholesterol containing diet feeding.

(Received March 13, 1971)

Synge $ら^{1)}$, Morrisら ${ }^{2)}$ 津野ら 含硫了ミノ酸S-Methyl-L-Cysteine Sulfoxide(Methiin と略称する）はキャベッを初め十字花科批よびアリウム 属植物に広く分布している。当教室に执いてはこのもの の栄盖学的価值についての研究 ${ }^{4) 5}$ が続けられて来たが, 一方近年含硫了ミノ酸であるメチオニン, シスチン, シ スティンなどが抗コレステロール作用を有すると云う報 告早 8) も見られることから, 同じく含硫アミノ酸である Methiin が脂質代謝に関連を有する可能性す考えられる ので, この物質の実験的過コレステロール症に対する影 霖を観察することにした。

本報ではシロネズミを種々のコレステロール食の条件 て飼育した場合の血清コレステロール値の変動, および それに対する Methiin 食の作用について観察したので その成績について報告する。

\section{実験材料拉よび方法}

\section{Methiin}

津野らすの方法によりキャベッから単離した Methiin
の結晶（融点 $173 \sim 174^{\circ} \mathrm{C}$ ）を使用した。構造式を図 1 に示す。<smiles>CS(=O)CC(N)C(=O)O</smiles>

図1. Methiin の構造

\section{2. 実験動物}

体重75 g 前後の Wistar 系シロネズミを 1 匹ずつ金網 のケージ中で室温 $20 \sim 25^{\circ} \mathrm{C}$ の環境で飼育した。

3. 飼料

表 1 に示すよ5な組成の飼料を作り, 実験に応じて適 当に組合せて使用した。飼料は自由に与え, 飼料摂取量 を 5 日目ごとに測定した。

4. 血清コレステロールの測定

シロネズミの頸動脈を切断して屠殺し，血液は $10 \mathrm{mg} /$ 
表 1 . 飼料組成

I . コール酸無添加餇料

\begin{tabular}{|c|c|c|c|}
\hline & $\begin{array}{c}\text { I } \\
\text { 基本飼料 }\end{array}$ & $\begin{array}{c}\text { II } \\
\text { Methiin } \\
コ レ ス \bar{~} \\
\text { ロール食 }\end{array}$ & 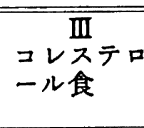 \\
\hline 乳㡀カゼイン & 12 & 12 & 12 \\
\hline 蔗＜wide>糖 & 36.6 & 35.48 & 35.85 \\
\hline 馬鈴薯測粉 & 36.6 & 35.47 & 35.85 \\
\hline オリーブ油 & 10 & 10 & 10 \\
\hline 塩化ュリン & 0.3 & 0.3 & 0.3 \\
\hline ビタミン混合* & 0.5 & 0.5 & 0.5 \\
\hline 塩 混 合** & 4 & 4 & 4 \\
\hline コレステロール & & 1.5 & 1.5 \\
\hline Methiin & & 0.75 & \\
\hline
\end{tabular}

II. コール酸添加飼料

\begin{tabular}{|c|c|c|c|}
\hline & $\begin{array}{l}\text { I } \\
\text { 基本飼料 }\end{array}$ & $\begin{array}{l}\text { II } \\
\text { Methiin } \\
\text { コレステ } \\
\text { ロール食 }\end{array}$ & $\begin{aligned} & \text { III } \\
& \text { コレステロ } \\
& \text { ール食 }\end{aligned}$ \\
\hline 乳製カゼイン & 16 & 16 & 16 \\
\hline 蔗＜wide>糖 & 68.9 & 65.9 & 67.4 \\
\hline オリーブ油 & 10 & 10 & 10 \\
\hline 塩化コリン & 0.3 & 0.3 & 0.3 \\
\hline ビタミン混合* & 0.5 & 0.5 & 0.5 \\
\hline 塩 混 合** & 4 & 4 & 4 \\
\hline コール酸 & 0.3 & 0.3 & 0.3 \\
\hline コレステロール & & 1.5 & 1.5 \\
\hline Methiin & & 1.5 & \\
\hline
\end{tabular}

IIに招いてては実験結果の項に示す如く 1 週間目と飼料 II はコレステロール $1 \%$, Methiin $2 \%$, 飼料皿はコレス テロール $1 \%$ と切換え 2 週間目に飼料II， III，共コレス テロールを除去し不足分は蔗糖を增加させておぎなった *ビタミン混合組成 $(1 \mathrm{~g}$ 中)
Vitamin A Palmitate

カルシフェロール

硝酸チアミン

Riboflavin

Nicotic Acid Amide

塩酸 Pyridoxin

Folic Acid

Pantothenic Acid $\mathrm{Ca}$

Vitamin $B_{12}$

Ascorbic Acid

$\mathrm{d} l-\alpha$-トコフェロール

**塩混合 $(\%)$

$\mathrm{NaCl}$

$\mathrm{Na}_{2} \mathrm{HPO}_{4} \cdot \mathrm{H}_{2} \mathrm{O}$

$\mathrm{K}_{2} \mathrm{HPO}_{4}$

$\mathrm{CaH}_{4}\left(\mathrm{PO}_{4}\right)_{2} \cdot \mathrm{H}_{2} \mathrm{O}$

$\mathrm{Fe}\left(\mathrm{C}_{6} \mathrm{H}_{5} \mathrm{O}_{7}\right) \cdot 5 \mathrm{H}_{2} \mathrm{O}$

$\mathrm{Ca}\left(\mathrm{C}_{3} \mathrm{H}_{5} \mathrm{O}_{3}\right)_{2} \cdot 5 \mathrm{H}_{2} \mathrm{O}$

$\mathrm{MgSO}_{4}$

KI
2500I.U.

200I.U.

$1 \mathrm{mg}$

$1.5 \mathrm{mg}$

$10 \mathrm{mg}$

$1 \mathrm{mg}$

$0.5 \mathrm{mg}$

$5 \mathrm{mg}$

$10 \mathrm{mg}$

$37.5 \mathrm{mg}$

$1 \mathrm{mg}$

蔗糖で $1 \mathrm{~g}$ とする。

4. 6

9.3

25.6

14.5

3. 2

34.9

7.0

0.9 $\mathrm{m} l$,ヘパリン0.1 $\mathrm{m} l$ を加えた容器に約 $2 \mathrm{~m} l$ 集めて混和 ᄂ， $3000 \mathrm{~g} ， 20$ 分間遠心沈測後血清を採取する。血清

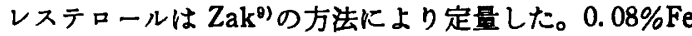
$\mathrm{Cl}_{3}$ （㬊 $\mathrm{CH}_{3} \mathrm{COOH}$ 液に溶解） $4.0 \mathrm{mlk} 0.1 \mathrm{~m} /$ の血清を 加えて混和した後, $1000 \mathrm{~g} ， 15$ 分間遠心沈澱をおこない その上清 $3.0 \mathrm{~m} l$ に濃硫酸 $2.0 \mathrm{ml}$ を加えて振盗し, 30 分 間室温に放置した後，日立分光光度計により $560 \mathrm{~m} \mu$ で 比色測定した。毎回同時に純コレステロール標準品(Sig $\mathrm{ma}$ をを用いて作慗した標準曲線と比較しコレステロール 量を算出した。

\section{実 験 結 果}

\section{1.コール酸除去飼料による実鋻}

コール酸無添加飼料をもちいてシロネズミを飼育し， 実験前， 4 週間目， 8 週間目にシロネズミを屠殺して血 清コレステロール値を観察した。

表 2. コール酸無添加飼料に括けるコレステロール食, Methiin ・コレステロール食扣よび対照シロネズ ミの血清コレステロール値 $(\mathrm{mg} / \mathrm{d} l$,平均値 \pm S.D.)

\begin{tabular}{|c|c|c|c|c|}
\hline & \multirow[b]{2}{*}{ 飼料 } & \multicolumn{3}{|c|}{ 飼育期間（週） } \\
\hline & & 0 & 4 & 8 \\
\hline I & 基本食 & $100.3 \pm 15.4$ & $107.0 \pm 9.4$ & $107.9 \pm 9.3$ \\
\hline II & $\begin{array}{l}\text { Methiin } \\
\text { コレステロー }\end{array}$ & 几食 & $120.7 \pm 13.0$ & $110.9 \pm 10.6$ \\
\hline III & コレステロー & ル食 & $141.0 \pm 14.0$ & $114.2 \pm 14.0$ \\
\hline
\end{tabular}

表 2 に示すようにコレステロール食シロネズミの血清 コレステロール值は 4 週間目で高くなり，8週間目では 再び低下する。コレステロールと共に Methiin を同時 に与えると 4 週間目の血清コレステロール値の上䄯は抑 えられる。

体重の增加は表 3 に示すよ5にコレステロール食群で 8 週間目で增加の傾向が見られるが Methiin を同時に 与えると体重の增加も明らかではなくなる。

飼料摂取量は基本食群は 1 日平均 $7.18 \mathrm{~g}$, Methiin+コ

表 3. コール酸無添加飼料における体重の変化

(g, 平均値 \pm S. D.)

\begin{tabular}{|c|c|c|c|c|}
\hline & \multirow[b]{2}{*}{ 飼料 } & \multicolumn{3}{|c|}{ 飼育期間（週） } \\
\hline & & 0 & 4 & 8 \\
\hline I & 基本食 & $77.4 \pm 11.7$ & $90.9 \pm 32.9$ & $112.2 \pm 31.0$ \\
\hline II & $\begin{array}{l}\text { Methiin } \\
\text { コレステロ }\end{array}$ & 一几食 & $109.1 \pm 34.0$ & $116.2 \pm 27.6$ \\
\hline III & コレステロ & 一ル食 & $102.3 \pm 34.6$ & $137.9 \pm 17.2$ \\
\hline
\end{tabular}

飼育開始時はすべての群の平均体重は76.0〜79.0g で初 めた。 


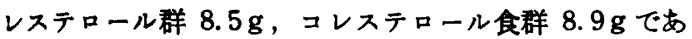
った。

\section{2. コール酸添加同料による実検}

コール酸はコレステロールの吸収に関連を有するので シロネズミの脂質代謝実験では通常飼料中に混じて用い られている。この実験ではュール酸を飼料中に加えて,

（表 1 ）飼育し，実験前，ならびに飼育 1 週間ごとに 4 週間, 血清コレステロールならびに体重の変化を観察し た。

コール酸を飼料に添加した場合の血清コレステロール 値は表 4 に示すよ 5 にコレステロール食群では 1 週間目 (1.5\% コレステロール食) で $250 \mathrm{mg} / \mathrm{d} l$ とピークにな り，飼料中のコレステロール濃度を $1 \%$ に落とした 2 週 間目ではやや減少し，その後コレステロールを飼料中よ り除去しても余り低下は認められない。Methiinをュレ ステロール食と同時に与えると血清コレステロールの上 升恃著明に抑制される。

表 4.コール酸添加飼料におけるコレステロール食,

Methiin・コレステロール食怙よび対照のシロ ネズミ血清コレステロール值

( $\mathrm{mg} / \mathrm{d} l$, 平均値)

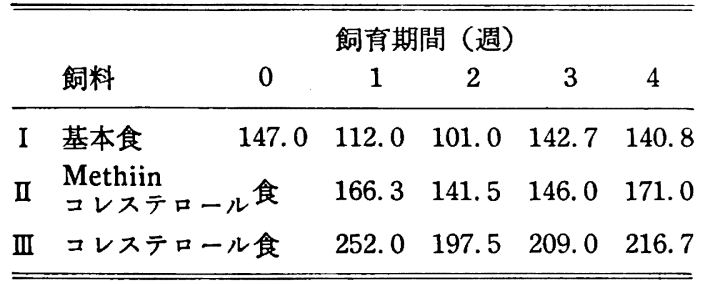

コール酸添加飼料て飼育した場合のシロネズミの体 重, 肝豚重量の体重に対寸る割合および脾蔵重量の体重 に対する割合は表 5 ～ 7 に示す通りであった。

表 5.コール酸添加飼料における体重の変化

( $\mathrm{g}$, 平均値)

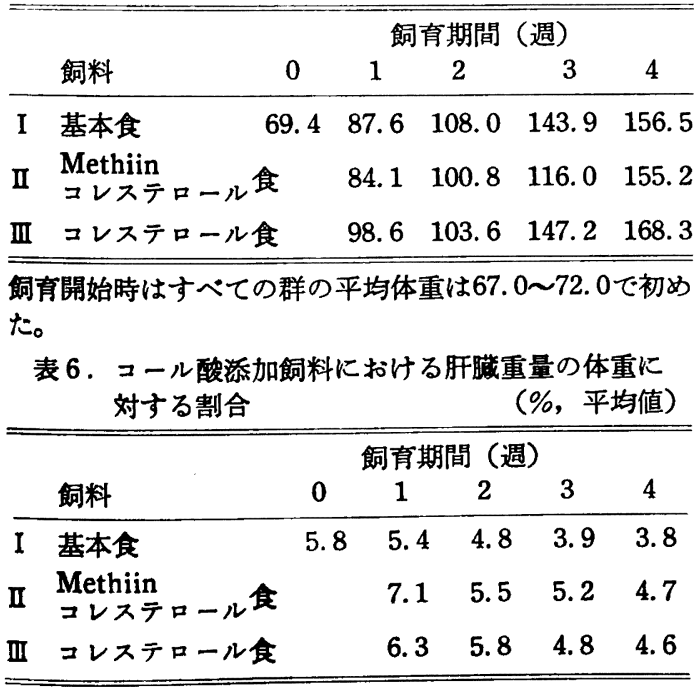

表 7 . コール酸添加飼料における脾臓重量の体重に 対する割合

(\%, 平均值)

飼育期間（週）

\begin{tabular}{llccccc} 
& 飼料 & 0 & 1 & 2 & 3 & 4 \\
\hline I & $\begin{array}{l}\text { 基本食 } \\
\text { II }\end{array}$ & $\begin{array}{l}\text { Metniin } \\
\text { コレステロール 食 }\end{array}$ & 0.281 & 0.439 & 0.332 & 0.406 \\
III & $\begin{array}{l}\text { コレステロール食 } \\
\text { コレス }\end{array}$ & 0.257 & 0.188 & 0.227 & 0.228
\end{tabular}

本実験では体重の增加はコレステロール食群, Methiin ナコレステロール食群扣よび対照群で余り差は琰められ ず，肝藏重量はコレステロール食群に增加の傾向が認め られたが, Methiin 添加によっても変化はみられなかっ た。一方脾蔵重量は $2 \%$ Methiin 食で急激な增加を示 した。

考察

コール酸無添加コレステロール添加飼料でシロネズミ を飼育した場合にはコール酸添加の場合に比して明らか に血清コレステロールの上䄯が低いことは Beher ら ${ }^{10)}$ の報告と一致する。しかしこのいずれにおいても血清コ レステロール值の上界を Methiin が抑制することは興 味あることである。

Methiin は十字花科およびアリウム属植物に多量に含 まれており (表 8$)^{3)}$ ，野菜から我々の体内に入る含硫了

\begin{tabular}{|c|c|c|}
\hline 属 & 植物名 & 含有量 \\
\hline アブラナ科 & 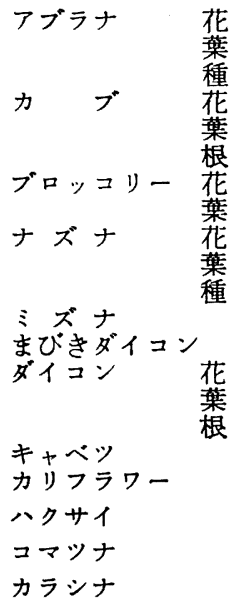 & $\begin{array}{r}370 \\
87 \\
220 \\
412 \\
153 \\
40 \\
721 \\
583 \\
566 \\
154 \\
325 \\
60 \\
60 \\
342 \\
60 \\
60 \\
590 \\
650 \\
50 \\
90 \\
25\end{array}$ \\
\hline ネギ科 & $\begin{array}{l}\text { ニンニク* } \\
\text { ラッキョウ } \\
\text { ニ ラ } \\
\text { ネ ギ } \\
\text { タマネギ } \\
\text { リーキ } \\
\text { ハナニラ }\end{array}$ & $\begin{array}{r}1110 \\
650 \\
450 \\
120 \\
100 \\
285 \\
454\end{array}$ \\
\hline
\end{tabular}

* ニンニクには Methiin の同属体である Alliinが 大部分であり Alliin としての値を示した。 
ミノ酸としては最も多いものではないかと考えられる。 このような意味あいから考えて従来から民間で云われて いる野菜食の動脈硬化症などの疾患の予防効果等を単に 低コレステロール食と云う意味から考えるだけでなく， また単に必須了ミノ酸からだけ解釈することなく，Methiin のような非必須了ミノ酸の観点から研究をするこ とも喿養学的に重要なことであると考える。

$2 \%$ のethiin 食を与えたシロネズミの脾蔵は肥大 し肉眼的にも色調は黒变していることは，このものが造 血機能に何らかの影響を及济していることを示唆してい るものと考えられ，この現象と脱コレステロール作用と の関連性は今後追求されるべき興味深い問題と考元られ る。

\section{総括}

キャベッより抽出した含硫アミノ酸, S-Methylcysteine Sulfoxide (Methiin) の抗コレステロール作用を シロネズミの血清コレステロール低下作用について報告 した。

（1）コール酸無添加飼料での実験ではコレステロール 食によりシロネズミの血清コレステロール值は 4 週間目 がピークとなり 8 週間目ではもとにもどったが，体重は
8 週間目で增加しており，体内への脂肪沈着が考えられ た。しかし Methiin 添加食はこの 4 週間目の血清コレ ステロールの上界と 8 週間目の体重增加の両作用を抑制 した。

(2) コール酸添加飼料での実験に批いても Methiinは 血清コレステロールの上年を明らかに抑制した。

(3) $2 \%$ Methiin 添加シロネズミにおいては脾臓の 肥大が認められた。

\section{文献}

1) Synge, R. M. L., Wood, J. C.: Biochem. J., 60, 15 (1955)

2) Morris, C. J., Thompson, J. F.: J. Am. Chem. Soc., 78, 1605 (1956)

3）津野貞子, 村上不二雄, 田添浩一, 菊本聡: ビタ ミン, 20, 93 (1960)

4) 津野貞子：ビタミン, 14, 665 (1958)

5) 津野貞子：ビタミン, 14, 671 (1958)

6) Howe, E. E., Bosshardt, D. K.: J. Nutr., 76, 242 (1962)

7) Bagchi, K., Ray, R., Datta, T.: Am. J. Clin. Nutr., 13, 232 (1963)

8）尾関英夫：大阪大学医誌，11，4969 (1959)

9) Zak, B.: Am. J. Clin. Pathol., 27, 583 (1957)

10) Beher, W. T., Baker, G. D., Anthony, W. L.: Am. J. Physiol, 199, 736 (1960)

（昭和 46 年 3 月 13 日受理） 